\author{
Stanisław Gaca \\ prof. dr hab. inż. \\ Politechnika Krakowska \\ Katedra Budowy Dróg i Inżynierii Ruchu \\ sgaca@pk.edu.pl
}

DOI: $10.35117 /$ A_ENG_17_08_04

\title{
Road transportation - selected aspects and the role of infrastructure development
}

\begin{abstract}
The article presents the problem of the development of road infrastructure in Poland in connection with the needs and the role of road transportation as an important branche of the national economy. The statistical data confi $\mathrm{rm}$ the extremely dynamic growth of freight and passenger transportation with use of roads in Poland. Such development is associated with anumber of negative phenomena, which are described in the article. The strategy and plans for expansion and remodeling of the road infrastructure in Poland are also described here, alongside its charactics. Special attention is devoted to the role of scientifi c research in the implementation of the described plans. The direction of the necessary changes to the design regulations in order to allow construction of safer and more effi cient infrastructure, are also indicated in this work.
\end{abstract}

Keywords: Road transportation; Road design; Design regulations

\section{Introduction}

Road transport is a very important branch of the economy in the European Union and thus also in Poland. There is a strong link between the efficiency of this transport, the extent of the road infrastructure and the efficiency of the economy. This is a reflection of in the strategic development programs of transport infrastructure of European Union countries. This is particularly true of countries where economic reforms dominated by the free market economy were introduced at the end of the 1990s. In Poland, this caused the increase of land transport of goods and passengers by means of road transport. Comparing the years 2014 and 2005, this increase was $59 \%$ for freight and $44 \%$ for passenger transport [2]. Such a large increase in the share of passenger and freight transport in road transport in Poland was achieved with a much lower dynamics of road infrastructure development, which caused the unfavorable increase in congestion, increased travel time and increased noise and air pollution.

In order to counteract the negative effects of road transport, the country is working to intensify and modernize the existing road network, and technical and organizational solutions are being implemented to make more effective use of the existing road network. In addition, the safety of all users of road infrastructure is of paramount importance. Such activities and identification of the main problems of road infrastructure development, as well as the presentation of the role of research in the development of modern road infrastructure and its operation, are devoted to this study..

\section{State and development of road infrastructure}

In assessing the state and development trends of road infrastructure, it is necessary to analyze these issues with reference to the development of road transport in Poland and the consequences of this development, which can be synthesized as follows:

- in the whole period since Poland's accession to the EU, a clear trend has been recorded for an increase in the share of road transport in freight transport (up to 83\% in 2014 in 
domestic land transport), with a significant decrease in the share of rail transport in these services;

- $\quad$ as a very high $(93 \%)$ the share of road transport in national inland passenger transport should be assessed. The significant increase in the share of passenger cars in passenger transport, ie $10.5 \%$ in 10 years;

- road transport, using petroleum fuels, produces greenhouse gases accounting for about $14.0 \%$ of total greenhouse gas emissions in Poland. Emissions increase as the number of vehicles increases, despite the technical development of engines that limit their individual emissions;

- road accidents are one of the most important adverse effects of road transport, but it should be noted that despite the increase in road traffic, a significant reduction in the number of accidents and their victims has been recorded in recent years. One of the reasons for this phenomenon is the development of road infrastructure and improvement of its technical and operational characteristics;

- the increase in the motorization of the new EU Member States, including Poland, and the increase in the share of heavy goods vehicles in freight transport are exerting additional pressure on the development needs of road infrastructure.

The efficient functioning of road transport requires a road infrastructure that meets basic performance requirements (capacity and adaptation to vehicle characteristics), safety, minimization of construction and operation costs, and minimization of adverse environmental impacts. Regardless of the technical and functional requirements stated, the following road infrastructure functions should also be considered:

- integration function - strengthening, tightening and expanding spatial economic links,

- area availability function - "sharing" of the space to be used,

- growth function - the basis of economic development,

- logistic chain link function - the basis for forming logistic systems.

In assessing the existing and planned road infrastructure, the level of fulfillment of the specified functions and technical requirements should be taken into account.

By the end of 2013, the public road network in Poland numbered over 415 thous. km, of which 262.6 thous. $\mathrm{km}$ had an improved surface (bituminous or concrete). The functional division of the road network in 2013 was as follows: domestic roads - 19.3 thous. km, provincial roads - 28.5 thous. $\mathrm{km}$, district roads - 125.3 thous. $\mathrm{km}$ and municipal roads - 242 thousand. $\mathrm{km}$ (only about $51 \%$ of hard surface). The density of paved roads was $91.2 \mathrm{~km} / 100$ $\mathrm{km} 2$ in 2013 and was territorially different (from $54,1 \mathrm{~km} / 100 \mathrm{~km}^{2}$ to $188 \mathrm{~km} / 100 \mathrm{~km}^{2}$ ) [11]. This is a value comparable to other EU countries. A significant difference lies in the length and density of motorways and expressways. Despite significant expansion in the years 2004 2016 Polish network of motorways and express roads (Fig. 1), their density differs considerably from the density of the leading countries belonging to economically in the EU. For example, in Germany, the value of the motorway density index in 2013 was $3,61 \mathrm{~km} / 100 \mathrm{~km}^{2}$, in France $2,11 \mathrm{~km} / 100 \mathrm{~km}^{2}$, in Italy $2,23 \mathrm{~km} / 100 \mathrm{~km}^{2}$, in Austria $2,05 \mathrm{~km} / 100 \mathrm{~km}^{2}$, and in Poland in 2015 it was only $0,5 \mathrm{~km} / 100 \mathrm{~km}^{2}$ (Considering dual expressway roads with technical characteristics similar to motorways, the value of this indicator was approx. $1,0 \mathrm{~km} / 100 \mathrm{~km}^{2}$ ) [2]. 


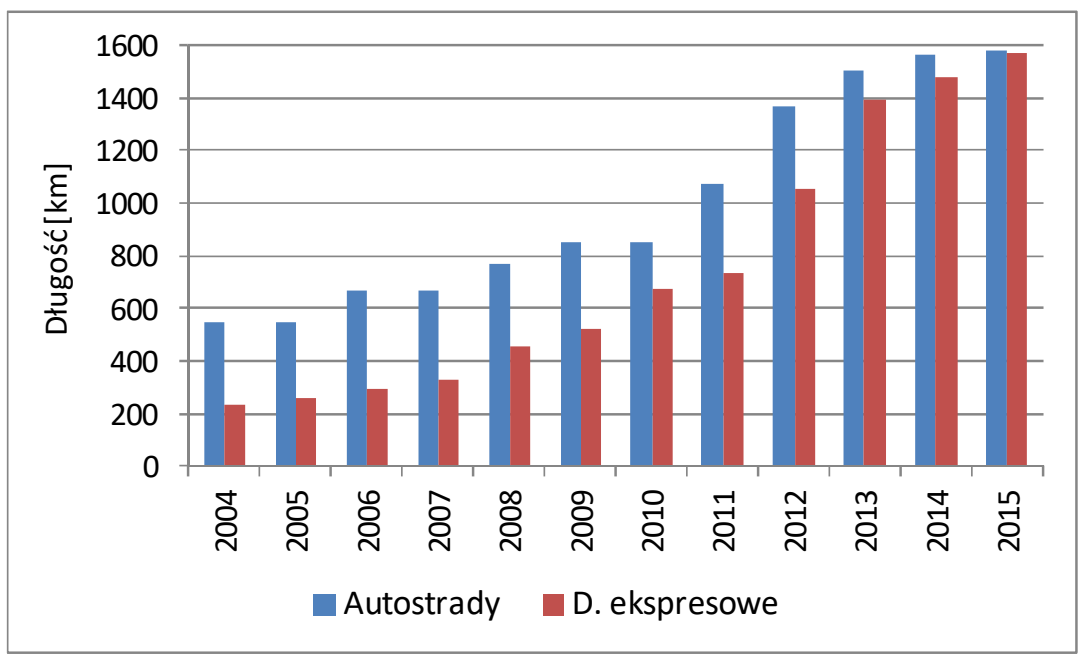

1. Changes in the length of the network of motorways and expressways in Poland in the years $2004-2015$

Despite the great achievements in the development of the network of highways and expressways, Poland's road infrastructure still requires further development and modernization. Such a statement results from the following shortcomings of the Polish road network [3, 6 , 10]:

- lack of a coherent network of motorways and highways, including the lack of continuity of the trans-European TEN-T road network as a high technical standard. The degree of hierarchization of the remaining network of roads is insufficient;

- multifunctionality of the predominant part of main roads and streets, mixed vehicle pipelines on roads (fast cars and trucks, tractors, bicycles and pedestrians);

- the occurrence of so-called "bottlenecks" that limit the efficient use of road network capacity;

- uneven distribution of high-class road networks and high throughput;

- the excessive casing of roads that perform high-traffic transit functions (including trucks). This results in functional conflicts, excessive environmental nuisance and increased risk of accidents, as well as the need for costly road safety solutions;

- A small proportion of roads adjusted to a load of $115 \mathrm{kN} /$ axle (only $25 \%$ of the national road surface is adapted to such pressures). Part of the road network is authorized for vehicles with $115 \mathrm{kN}$ / axle load only in administrative mode, which means that the surface of these roads will be destroyed faster than expected in the design;

- technical errors resulting from the occurrence of traffic accidents, deficiencies in equipment for unprotected traffic participants;

- a bad technical condition of a large part of the road network resulting from insufficient funds allocated to the maintenance of this network.

It is not possible to collect full technical data on the road network due to lack of monitoring system for the entire road network. Such monitoring is carried out only in relation to national roads and in some province roads. On the basis of the assessment of road surface conditions in 2015 , it was found that $60.6 \%$ of the surface was in good condition, $25.3 \%$ in unsatisfactory condition and $14.1 \%$ in bad condition [8]. This is a clear departure from data from 2003, when $59.9 \%$ of national road surfaces were unsatisfactory and bad overall.

In response to the problems and limited efficiency of the road network in Poland, its development programs are being implemented. The general purpose of these programs is defined as: increase transport accessibility/create high-quality connections between major ag- 
glomerations while improving traffic safety [10]. The specific objectives of the transport development strategy, including the development of the road network, are defined as follows:

- creation of a modern, coherent transport infrastructure network,

- improvement of the organization and management of the transport system,

- $\quad$ safety and reliability,

- reducing the negative impact of transport on the environment,

- building a rational model for financing infrastructure investments.

The specific objectives set out above are related to the operational objectives of the road sector, covering up to 2023. [10]:

- completion and modernization of the road network, including TEN-T,

- reducing average travel time between regional centers by $15 \%$,

- $\quad$ improving road safety,

- improving the capacity of main road arteries,

- obtaining a smooth ride on long stretches of road,

- adjustment of the national road network to $115 \mathrm{kN} /$ axle load,

- relieving the agglomeration from transit traffic,

- completion of modernization of the main transport routes, where work has already started.

The overall plan for the development of the national road network in the perspective up to 2025 includes National road construction program 2014-2023 (with a view to 2025) which is annexed to resolution 156/2015 of the Council of Ministers of 8 September 2015. Although the program is currently being reviewed, the priorities set out in it:

- construction of motorways and expressways,

- construction of bypasses,

- road safety,

with the following implementation indicators:

- increase the density of expressways to $17,5 \mathrm{~km} / 1000 \mathrm{~km} 2$,

- increase the density of motorways and expressways to $22,7 \mathrm{~km} / 1000 \mathrm{~km} 2$,

- obtaining the total length of new sections of motorways and expressways $-3900 \mathrm{~km}$,

- construction of 57 new bypasses,

- reduction the number of fatalities by at least $40 \%$ and severely injured by at least $41 \%$.

Road accidents and their costs are a very serious problem throughout the EU. It is estimated that the cost of road events per year is about 180 billion euros in the EU countries, and in Poland, these costs in 2015 were estimated at 48.2 billion. These costs include accidents costs of PLN 33.6 billion and costs of road collisions of PLN 14.6 billion [5]. It should be noted, however, that since 1997, the highest number of accidents (66.5 thousand) and the highest number of fatalities (7311) has been observed, a significant improvement in road safety, ie the reduction of accidents and their victims (Fig. 2). 


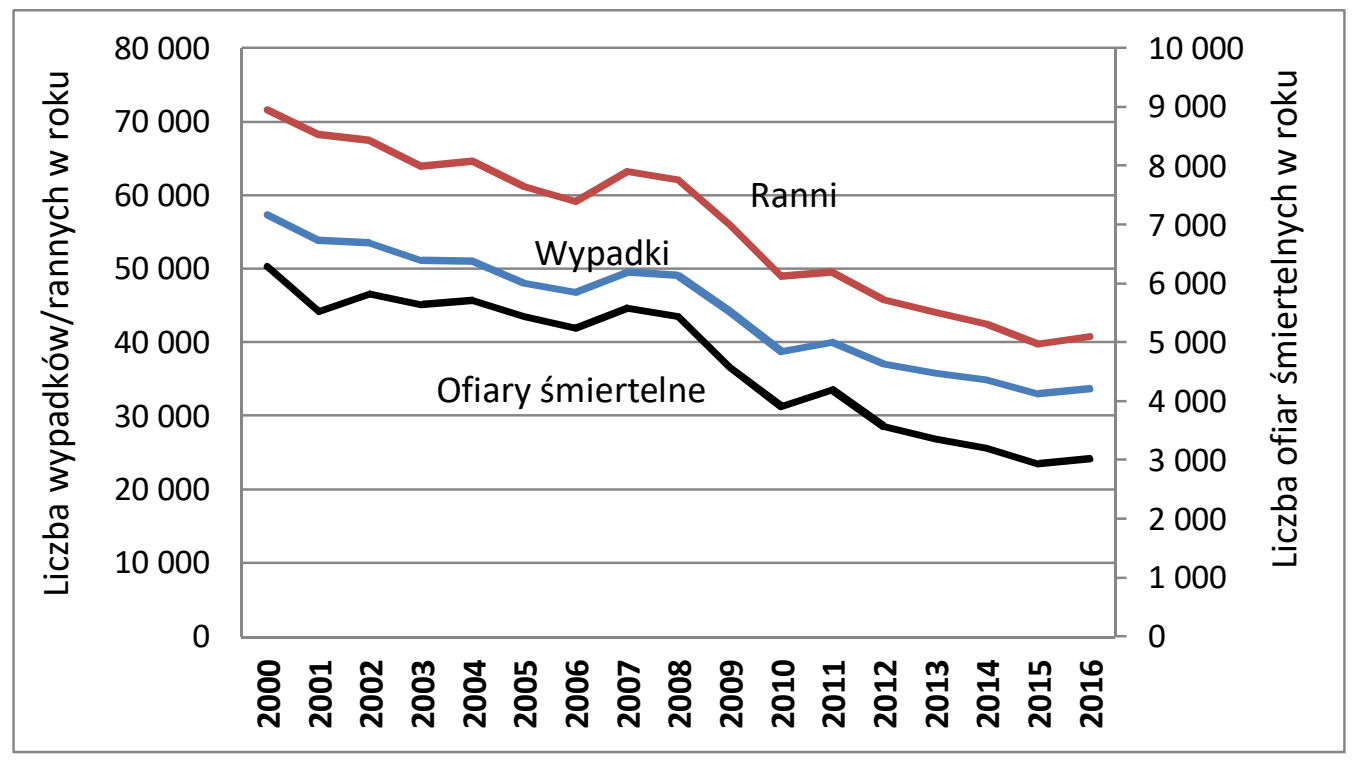

2. Trends in the number of road accidents and their victims in Poland in 2000-2016

In the period of 10 years (2007 - 2016), the number of accidents decreased by $32.0 \%$ and the number of accidents decreased by $45.8 \%$. This was achieved with a $52 \%$ increase in the number of registered motor vehicles in 2006-2015. Traffic in Poland is still assessed as being at high risk of accidents. Demographics of the number of fatalities in road accidents in Poland amounting to 7.7 deaths in 2015/100 thousand. The population is significantly higher than the EU average (5.1 deaths per 100000 inhabitants). The mortality rate per 100 accidents, which in 2016 was 9.0 in Poland at 2.4 in the EU.

Improving road safety is not only connected with road infrastructure but is an interdisciplinary task, as reflected in National Road Safety Program 2013 - 2020 [6]. It uses the "safe system" methodology, defining its five pillars: safe man, safe road, safe speed, safe vehicle, medical rescue and accidental care. For the pillar of "safe road", two priority actions were adopted:

- priority 1 - implementation of road safety standards eliminating the greatest road traffic hazards;

- priority 2 - development of road infrastructure safety management system.

In addition to the national road construction program, regional self-government roadmaps are also important, which play an important role in "making available" a given space for development. The road infrastructure development strategy envisages the development of local roads and their connections with the network of national and provincial roads, as well as the removal of transit traffic from the towns which are also in the roads of the voivodships. Transformation of self-government roads is a much wider problem, requiring separate studies, which are omitted in this article.

In summary of the short characterization of the state and development of road infrastructure in Poland it can be stated that:

- despite the significant increase in the length of expressways and motorways, their density is insufficient in light of the increasing role of road transport. Therefore, it is planned to supplement the network by 2025 by $3900 \mathrm{~km}$;

- it is necessary to liquidate the so- "Bottlenecks" that limit the effective use of the existing road network and improve the uniformity of the high-tech road network and high throughput networks;

- road access control policies are not adequately implemented in relation to land use impacts in the vicinity of roads; 
- the poor technical condition of a large part of the road network requires the implementation of a road improvement program and an increase in maintenance expenditure;

- maintaining a favorable trend in the reduction of accidents and their victims requires the implementation of a road safety management system not only on national roads but also on local roads.

\section{Scientific and practical challenges in the development of Polish road infrastructure}

One of the major challenges facing the scientific community and practitioners is the formulation of design principles and the choice of construction technologies, corresponding to future knowledge, and to a lesser extent use of the practice and knowledge of the day. The road is often seen as a building with a high potential for innovative solutions and this should be reflected in the design and development practice.

When attempting to diagnose future research needs and taking into account the experience gained in the road network development program in Poland and the research undertaken in recent years, it may be necessary to undertake or continue research in the following problem groups, related to geometric road design and traffic management $[3,4]$ :

- the impact of road infrastructure on traffic safety and the updating of road design principles for improving traffic safety,

- the shaping of cross-sections of roads and streets, including their new functions, including better adaptation to the needs of pedestrians and cyclists, while meeting the requirements of mobility and safety - introducing new solutions, eg $2+1$ crosssections, multifunctional cross-sections,

- rules for the planning and design of road bypasses and the reconstruction of roads on sections of road crossings,

- the conditions of road accessibility and the resulting design principles, while taking into account safety criteria, traffic performance and minimizing road and traffic environmental impacts,

- $\quad$ security risks for unprotected traffic participants, equipment for unprotected traffic participants in high-speed trains,

- shaping roads due to the criterion of homogeneity of traffic conditions on long stretches of the road,

- efficiency and cost of road infrastructure functioning in short-term and seasonal variability of traffic,

- trends in car park changes and their impact on road and junction design as well as pavement design, with particular regard to the possibility of introducing long vehicles,

- research on the effectiveness of new solutions promoted in foreign practice and implemented as experimental in national practice,

- the impact of Intelligent Transport Systems (ITS) on road design and traffic management, practical recommendations for design practice,

- new road network management methods taking into account all the cost components of the "life cycle" of the infrastructure.

A separate group is the study of materials and road pavement construction, which must answer questions about how to build durable pavements, taking into account the cost criterion and the environmental requirements. A major challenge, in this case, is to adapt the construction of roads and engineering facilities to the observed and predicted climate change.

The need for stronger support for the development and transformation of road infrastructure has been recognized by the General Directorate for National Roads and Motorways and the National Center for Research and Development, which in 2015 announced a research 
competition under the Road Innovation Program. In the first competition, the following research problems were selected:

- the use of recycled materials,

- road bituminous and modified in Polish climatic conditions,

- alkaline reactivity of domestic aggregates,

- road noise protection,

- modern methods of recognizing ground in road construction,

- principles of traffic forecasting including other means of transport,

- modern methods of calculating capacity and evaluation of traffic conditions for roads outside urban agglomerations, including for expressways,

- road safety equipment,

- the impact of time and operating conditions on the durability and functionality of road safety components,

- the efficiency of the $2+1$ cross-section, with particular regard to the different solutions separating the directions of movement,

- the impact of advertising on the level of traffic safety,

- selection of permissible traffic speeds on the roads, including dynamic traffic management,

- the impact of the use of Intelligent Transport Systems services on the level of road safety,

- $\quad$ parking places at the travel service (MOP)

- experimental signs of roads in the aspect of the behavior of the participants.

The summary illustrates the current practical problems in the field of construction and reconstruction of roads, whose solution is sought through scientific research. Equally, however, the limited scope of road safety investigations should be pointed out as an important determinant of road design and maintenance. This is particularly relevant for the assessment of the impact of particular road infrastructure elements on traffic safety and the methods of forecasting measures of this safety.

The current development of road safety research should be analyzed in the light of the following groups of research:

- $\quad$ using traffic incident data (trend analysis, pre-and post-tuple analysis, regression analysis, neural networks, reliability models);

- behavioral (registration of indirect measures in real traffic, laboratory tests, driving simulator tests, interviews and surveys)

- using selected groups of models (physical, simulation, analytical),

- combining statistical research with behavioral and model analyzes.

Usually, the practical aims of this research are to: identify infrastructure threats with high potential for improving traffic safety; eliminating incorrect design solutions from the design practice and introducing innovative solutions; development of road infrastructure safety management tools.

Technological progress makes it necessary to direct traffic safety studies, among others on:

- the impact of vehicle equipment on decision support systems and communication systems between vehicles for traffic safety,

- the effects of participation in autonomous vehicles, particularly when combined with the use of "traditional" vehicles;

- new ITS measures and their impact on traffic safety,

- use new traffic congestion management methods in real time traffic management and manage this in real-time. 
In general, research and analysis of existing solutions are the basis for formulating the directions and scope of changes in the design of road infrastructure. As a result of studies of various research works, the following general directions of additions and necessary changes in technical and construction regulations may be formulated:

- the introduction of required traffic safety standards by setting acceptable risk classes with the development of risk assessment tools,

- the introduction of methods for assessing the impact on the safety of deviations from technical conditions and the use of substandard solutions,

- the introduction of formal requirements for shaping the safe road environment and forms of development of this environment,

- the creation of a formal basis for the construction of "self-explanatory" roads, ie clearly separated functions and technical standards consistent with the adopted function, which should be uniquely identified by users,

- integration of geometric design with the design of traffic safety measures and introduction of speed management measures,

- standardization of cross sections of roads with the elimination of dangerous sections, adjustment of limit values for roads, junctions, and nodes as well as visibility requirements for modern traffic models taking into account changes in road characteristics, vehicle characteristics and behavior of traffic participants,

- designing road equipment and its surroundings to provide safe solutions, including "forgiving" driver errors,

- the introduction of separate technical groups of restrictions on the parameters of roads, junctions and junctions, depending on their location and actual functions,

- determining specific traffic calming requirements for different uses of traffic,

- clarification and extension of the principles of dimensioning devices for pedestrian and bicycle traffic,

- incorporating in the geometric design and organization of the movement of equipment the means of intelligent transport systems that increase the safety of traffic.

The above list of suggestions for changes in the design rules should be evaluated in the context of the present time Technical conditions for public roads and their location. These were first published in March 1999 and slightly updated in 2015, but without the majority of the above recommendations. Hence the need for more thorough verification of the mentioned Technical conditions....

In addition to the design provisions, a variety of design aids are also important, including tools introduced by the Directive 2008/96 / EC of the European Parliament and of the Council of 19 November 2008 on road infrastructure safety management [1]. This directive has been implemented in national law by amending the Act on Public Roads. Road infrastructure management has been introduced:

a) in relation to road infrastructure plans and projects:

- assessment of the impact of planned roads on brd,

- roadside brd audits in the planning and design stages and at the time of commissioning and after one year of use,

b) in relation to existing road infrastructure:

- roadside inspections, including road surveys to identify roadside faults and roadblocks to equip roads that adversely affect road conditions,

- road events analysis to classify dangerous sections and identifications of so-called "black spots", ie places with a particularly high accident risk,

- implementing corrective actions in the road network based on diagnoses. 
A separate group of research and development is the development of innovative technological solutions together with IT applications, aimed at streamlining traffic flow and improving road safety. Their use is increasingly being taken into account in the design of road infrastructure, especially in the areas of high traffic congestion and in highways in urban areas. At present, the greatest potential of ITS use in the area of road transport is related to the collection of road infrastructure charges, traffic monitoring, management support systems and road safety and general information for travelers.

The above-selected list of research questions and directions of changes in the design rules should be supplemented with a general overview of the most important tasks in the development of road infrastructure in the 21 st century. The trends of this development are analyzed in a number of EU research projects as well as within the framework of the activities of the CEDR (Conference of European Directors of Roads) and FEHRL (Forum of European National Highway Research Laboratories). On the basis of these analyses, [9] the most important directions of road infrastructure development, which can be summarized as follows:

- "safe and reliable roads". The main goal is to improve the safety and efficiency of roads by better planning the new infrastructure and improving the existing infrastructure management system. Management of the road and traffic data collected from various sources should play a very important role, which will lead to the development and individualization of information systems. Road maintenance and traffic management should include taking into account the changing climate. It will be necessary to adapt the roads to the changing demand for freight;

- " $\quad$ smart roads". The main goal is to improve information flow, reduce traffic noise and improve travel comfort. This is achieved through better collection and processing of a broad set of data that will influence road maintenance and traffic management. It is assumed that the existing ITS solutions will be used. This group of activities also includes innovative and "intelligent" materials and technologies in the construction and maintenance of road infrastructure;

- "energy efficient roads". The aim is to reduce and optimize energy use in the construction and maintenance of road infrastructure, as well as the introduction of energy recovery and renewable energy solutions through installations integrated with road infrastructure. In the construction of roads, materials and technologies with reduced energy requirements should be used;

- "low polluting roads". The aim is to reduce emissions from vehicle traffic and natural disasters while taking account of increasingly restrictive levels of emission limits. One of the main problems is the reduction of noise emissions, eg through innovative road surfaces, and in the case of reducing noise emissions, eg using photocatalytic materials;

- $\quad$ "roads of contributing to the environment of life". The aim is to optimize infrastructure solutions that provide economic and social connectivity while taking into account natural, aesthetic, landscape and cultural aspects. This means moving away from the dominant role of transport for other functions, especially in urban areas (improving comfort when being in the road/street area);

- „roads as an element of sustainable development ". The goal is to develop the infrastructure in line with the requirements of natural environment protection, rationalization of construction and operation costs and high quality of operation. The role of cost analysis in the "life cycle" and the health aspects of materials used will be strengthened. This is the task of the "energy-efficient road" and "low emission road"";

- „roads as an innovation carrier ". Road infrastructure solutions should keep pace with the innovations introduced by the car industry (integrating innovative vehicle solutions with road solutions). The development and transformation of road infrastructure create 
opportunities for the implementation of innovative construction materials and technologies, as well as for the implementation of innovative management systems..

\section{Conclusions}

The growing role of road transport in freight and passenger transport in Poland causes constant pressure on the development of road infrastructure, which determines the smooth functioning of the economy. The existing road infrastructure, despite its considerable progress since Poland's accession to the EU, is characterized by many shortcomings, which are gradually eliminated.

On the basis of the overall assessment of the road network in Poland, the main activities in the area of maintenance, reconstruction, and development of the road network can be indicated: the addition of a network of motorways and express roads to a coherent network of highways; eliminating the so-called "bottlenecks" that limit the efficient use of the capacity of the existing road network; lengthening of the road network adjusted to $115 \mathrm{kN} /$ axle; improvement of technical condition of roads, reconstruction of road sections and places of accident concentration; construction of bypasses leading to transit traffic from urban areas.

In rebuilding and developing the road network, very important planning and design criteria are: safety and efficiency of traffic; reduction of emissions, including greenhouse gas emissions and noise emissions; limitation of water pollution. Compliance with these criteria in practice, along with other functional and economic criteria, requires continuous improvement of the design rules.

Design rules should be formulated mainly on the basis of experience from existing roads and the results of research and development. It is therefore extremely important to identify the most important research needs arising not only from the assessment of existing road infrastructure but also on the needs of the anticipated trends in vehicle construction, transport infrastructure and how it is used. Traffic safety is particularly important in this case, and the focus of research is to seek answers to the following questions: the influence of vehicle equipment on decision support systems and vehicle communication systems on traffic safety; effects of participation in autonomous vehicles, especially when combined with the "traditional" vehicles; impact of new ITS measures on traffic safety; The possibilities and scope of using new ways of mass data collection in analysis and management of real-time traffic safety. An important research group is a research to develop road infrastructure management tools, including safety management. The development of Intelligent Transport Systems should play a particular role. Their greatest potential in the area of road transport is related to the collection of fees for the use of road infrastructure, traffic monitoring, management support systems and road safety and general information for travelers.

Research descriptions often neglect their impact on the creation of new solutions, and it is, therefore, necessary to emphasize their focus so as to focus on issues related to the achievement of strategic goals for future road construction and operation. These paths should be characterized by: safety and reliability; using smart technical solutions; energy efficiency of construction and operation; low emission of pollutants; a significant role in the positive cocreation of the living environment; adapting to the principles of sustainable development; creating innovative solutions.

\section{Source materials}

[1] Dyrektywa Parlamentu Europejskiego i Rady z 19 listopada 2008 roku w sprawie zarządzania bezpieczeństwem infrastruktury drogowej 2008/96/WE. (Dz.U. UE L.319/59)

[2] EU Transport in Figures - Statistical pocketbook 2016. http://ec.europa.eu/transport/facts-fundings/statistics/index_en.htm, 10.04.2017 r. 
[3] Gaca S., Jamroz K., Kieć M. i inni: Kształtowanie infrastruktury drogowej spełniającej standardy bezpieczeństwa ruchu”. Projekt badawczy POIG.01.01.02-10-106/09-01 „Innowacyjne środki i efektywne metody poprawy bezpieczeństwa i trwałości obiektów budowlanych i infrastruktury transportowej w strategii zrównoważonego rozwoju", Politechnika Łódzka/Politechnika Krakowska, 2010 - 2012 (manuskrypt).

[4] Gaca S.: Badania naukowe i ich rola w przekształcaniu sieci drogowej. Zeszyty naukowe Politechniki Rzeszowskiej „Budownictwo i inżynieria środowiska”, Zeszyt nr 59 $(3 / 2012 / 1)$ s. $69-79$

[5] Jaździk-Osmólska A.: Wycena kosztów wypadków i kolizji drogowych na sieci dróg w Polsce na koniec roku 2015, z wyodrębnieniem średnich kosztów społecznoekonomicznych wypadków na transeuropejskiej sieci transportowej. Krajowa Rada Bezpieczeństwa Ruchu Drogowego, Warszawa, 2016.

[6] Narodowy Program Bezpieczeństwa Ruchu Drogowego 2013 - 2020. Dokument przyjęty przez KRBRD uchwałą nr 5/2013 $\mathrm{z}$ dnia 20.06.2013 r. www.krbrd.gov.p1/files/file/NP-BRD-2020_przyjety_przez_KRBRD.pdf , 10.01.2017 r.

[7] Program budowy dróg krajowych na lata 2014-2023 (z perspektywą do 2025 r.) Załącznik do uchwały nr 156/2015 Rady Ministrów z dnia 8 września 2015 r.

[8] Raport o stanie technicznym nawierzchni sieci dróg krajowych na koniec 2015 roku. www.gddkia.gov.pl/userfiles/articles/r/raporty_18751//Raport\%20stan\%20na\%20konie c\%202015\%20v11.pdf, 10.04.2017 r.

[9] Straße im 21. Jahrhundert - innovativer Straßenbau in Deutschland. Bundesministerium für Verkehr, Bau, und Stadtentwicklung, Bonn, 2012.

[10] Strategia rozwoju transportu do 2020 roku (z perspektywą do 2030 roku) Ministerstwo Transportu, Budownictwa $\quad$ i $\quad$ Gospodarki Morskiej http://mib.gov.pl/media/3511/Strategia_Rozwoju_Transportu_do_2020_roku.pdf 10.01.2017 r.

[11] Transport drogowy w Polsce w latach 2012 i 2013. Główny Urząd Statystyczny. Informacje i opracowania statystyczne. Warszawa, 2015. 